\title{
SEBARAN SUHU PERMUKAAN LAUT MENGGUNAKAN CITRA SATELIT LANDSAT-8 DI PERAIRAN TELUK KENDARI SULAWESI TENGGARA
}

\author{
Distribution of Sea Surface Temperature Using Landsat-8 Images in \\ Kendari Bay, Southeast Sulawesi
}

\author{
Meambo Trikun Andeleu ${ }^{1}$, La Ode Muhammad Yasir Haya ${ }^{2}$, dan La Ode Alirman Afu ${ }^{3}$ \\ ${ }^{1}$ Mahasiswa Jurusan Ilmu Kelautan, \\ Fakultas Perikanan dan Ilmu Kelautan, Universitas Halu Oleo. \\ Jl. H.E.A Mokodompit Kampus Hijau Bumi Tridharma Anduonohu Kendari 93232, Telp/Fax: (0401) 3193782 \\ ${ }^{2}$ Surel: lmyasir.haya@gmail.com \\ ${ }^{3}$ Surel: alirmanotsudari@yahoo.co.id
}

\begin{abstract}
Abstrak
Tujuan Penelitian ini mengetahui sebaran SST melalui analisis citra satelit landsat- 8 di Teluk Kendari. Manfaatnya diharapkan dapat memberikan data dan informasi kepada para pengambil kebijakan tentang pengelolaan pesisir dan laut di lokasi studi. Nilai SST diduga menggunakan transfromasi digital number ke nilai radians dan nilai suhu kecerahan. Analisis data menggunakan analisis regresi antara data pengukuran lapangan dan nilai kecerahan. Hasil penelitian menunjukkan terdapat korelasi yang kuat antara SST pengukuran lapangan dan SST dari citra landsat yakni mencapai 0,729. Konsentrasi SST pada Desember 2018 berdasarkan algoritma estimasi SPL berkisar antara $28.5^{\circ} \mathrm{C}-31.8^{\circ} \mathrm{C}$ sedangkan pada Februari 2019 , nilai suhu berkisar antara $28.7^{\circ} \mathrm{C}-33.0^{\circ} \mathrm{C}$.
\end{abstract}

Kata Kunci : Suhu Permukaan Laut, Algoritma Estimasi, Citra Landsat-8 TIRS, Teluk Kendari.

\begin{abstract}
The purpose of this study was to know the distribution of SST through transformation of digital number from landsat- 8 images in Kendari Bay. The research was expected to provide data and information regarding marine and coastal management at the study area. The SST from landsat images were predicted through transformation of digital number to the radiance value and brightness temperature value. Data analysis used regression analysis between SST in situ and brightness temperature value from landsat. Results showed that there was a strong correlation between SST in situ and SST from landsat images reached 0,729 The SST concentration in December 2018 ranged from $28.5^{\circ} \mathrm{C}-31.8^{\circ} \mathrm{C}$ based on the SST estimation algorithm while in February 2019 , the SST value ranged from $28.7^{\circ} \mathrm{C}-33.0^{\circ} \mathrm{C}$.
\end{abstract}

Keywords: Sea surface temperature, estimation algorithm, Landsat 8 TIRS, Kendari Bay.

\section{Pendahuluan}

Teluk Kendari merupakan salah satu ikon Kota Kendari yang secara ekonomi memiliki peranan yang sangat strategis dalam menopang aktivitas perekonomian dan lalulintas barang dan jasa di Provinsi Sulawesi Tenggara. Secara administratif Teluk Kendari mempunyai luas sekitar 29,5 $\mathrm{km}^{2}$ dan memiliki wilayah yang sangat strategis. Seperti daerah-daerah lain di Indonesia, wilayah Perairan Teluk Kendari memiliki dua musim yakni, musim penghujan dan musim kemarau. Musim penghujan dan musim kemarau merupakan faktor utama yang menjadi penyebab terjadinya perubahan lingkungan di Perairan Teluk Kendari. Faktor-faktor yang mempengaruhi perubahan musim di Teluk Kendari yaitu, kelembaban udara, kecepatan angin, curah hujan, penyinaran matahari dan temperatur atau suhu perairan.
Saat ini, Teluk Kendari diduga mengalami penurunan kualitas lingkungan perairan dari tahun ke tahun akibat dari berbagai aktivitas yang tidak memperhatikan kaidah lingkungan, seperti; pembuangan sampah, bahan pencemaran, reklamasi, pembangunan fisik, dan permasalahan banjir. Akibatnya, sejumlah parameter kualitas perairan Teluk Kendari mengalami perubahan dan dinamika yang cepat. Beberapa parameter kualitas perairan tersebut antara lain; salinitas, $\mathrm{pH}$, oksigen terlarut (DO), sedimen/material tersuspensi, kecerahan, dan suhu perairan. Dari semua parameter kualitas perairan, parameter suhu (temparatur) memainkan peran penting bagi keberlangsungan hidup berbagai organisme di Teluk Kendari.

Suhu merupakan besaran fisika yang berhubungan dengan kandungan energi panas semakin tinggi energi panasnya semakin 
tinggi pula suhunya. Suhu perairan merupakan salah satu faktor yang sangat penting bagi kehidupan organisme di lautan karena suhu dapat mempengaruhi aktifitas metabolisme dan perkembangbiakan suatu organisme. Suhu Pemukaan Laut (SPL) atau Sea Surface Temperature (SST) umumnya sering digunakan dalam bidang kelautan maupun perikanan yang merupakan bagian dari suhu perairan secara keseluruhan. SPL dipengaruhi oleh panas matahari, arus permukaan, keadaan awan, upwelling, divergensi dan konvergensi terutama pada daerah muara dan sepanjang garis pantai (Arief et al., 2015). Perubahan suhu juga dapat menjadi faktor yang mempengaruhi migrasi hewan atau organisme. Suhu mempengaruhi siklus biogeokimia dan kualitas habitat perairan. Beberapa faktor meteorologi ikut berperan, yaitu: curah hujan, penguapan, kelembaban udara, suhu udara, kecepatan angin dan intensitas radiasi matahari (Arief et al., 2015).

Sayangnya, informasi mengenai dinamika suhu permukaan laut (SPL) di Teluk Kendari belum tersedia dengan baik. Untuk mengisi kekosongan data dan informasi SPL Perairan Teluk Kendari, maka penelitian ini sangat penting dilakukan. Penelitian ini menggunakan pendekatan penginderaan jauh untuk memetakkan sebaran dan dinamika SPL di Teluk Kendari. Pada beberapa hasil penelitian yang ditemukan jenis data citra yang digunakan adalah data osean color (Aqua MODIS) untuk cakupan wilayah yang sangat luas, namun penelitian ini mencoba menggunakan data Citra Landsat-8 TIRS karena area penelitian sangat kecil (Teluk Kendari) dengan resolusi spasial Landsat $(30 \mathrm{~m})$. Pada Citra Landsat, keberadaan band thermal (thermal infrared sensor-TIRS) digunakan untuk mengestimasi model sebaran suhu permukaan laut di perairan.

Kualitas suhu di Perairan Teluk Kendari sangat dipengaruhi oleh kondisi lingkungan yang dapat mempengaruhi tingkat eksistensi perairan, baik berasal dari darat ataupun dari laut itu sendiri. Suhu Perairan Teluk Kendari selalu berubah-ubah sebab dipengaruhi oleh penetrasi dari sinar matahari.

Adapun tujuan dalam penelitian ini adalah: 1) mengetahui kisaran SPL in-situ dan ekstraksi Citra Landsat-8, 2) mengetahui distribusi sebaran suhu permukaan laut di Perairan Teluk Kendari, Sulawesi Tenggara. Manfaatnya diharapkan dapat memberikan data dan informasi kepada para pengambil kebijakan tentang sebaran suhu permukaan laut (SPL) di Perairan Teluk Kendari. Adapun kegunaannya diharapkan dapat menjadi sumber informasi dan referensi bagi para peneliti selanjutnya.

\section{Bahan dan Metode}

Penelitian ini dilaksanakan Desember 2018 - Mei 2019, yang meliputi pengukuran langsung sampel suhu permukaan laut (insitu) pada Tanggal 08 Desember 2018. Pengolahan data citra satelit Landsat-8 TIRS yang dilakukan di Laboratorium Komputasi GIS dan Pemodelan FPIK UHO. Lokasi penelitian ini dilaksanakan di perairan Teluk Kendari, Sulawesi Tenggara. Penentuan titik penelitian, sampel diambil 20 titik koordinat.

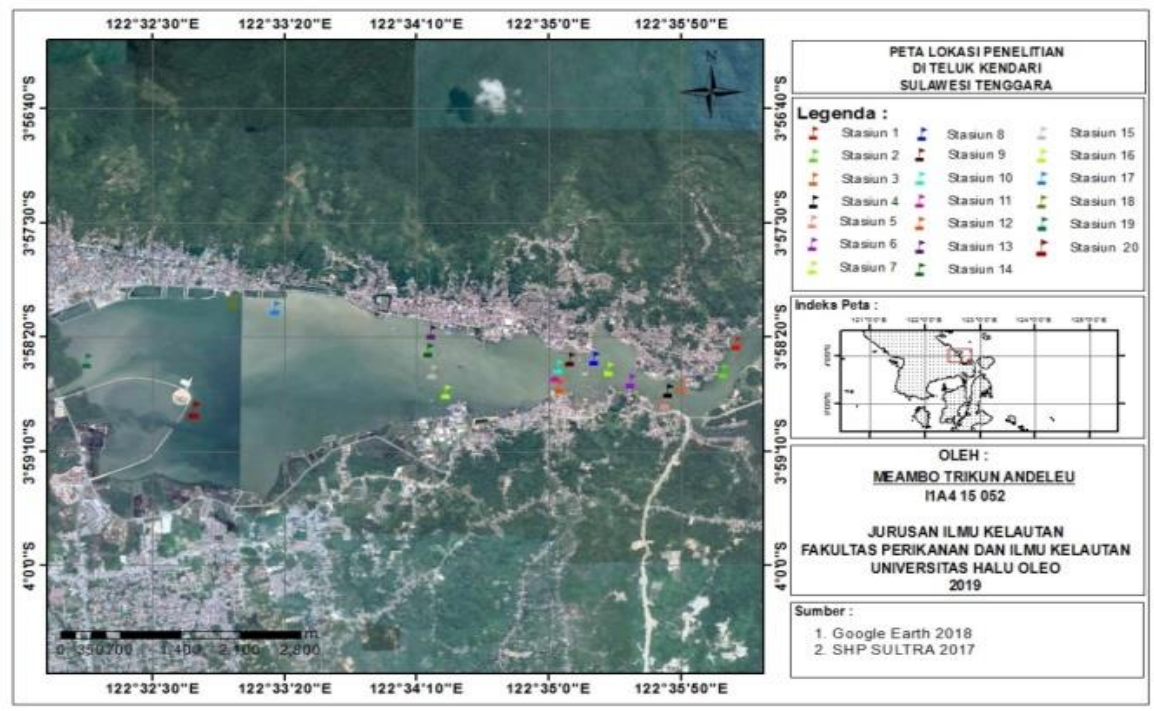

Gambar 1. Peta Lokasi Penelitian 


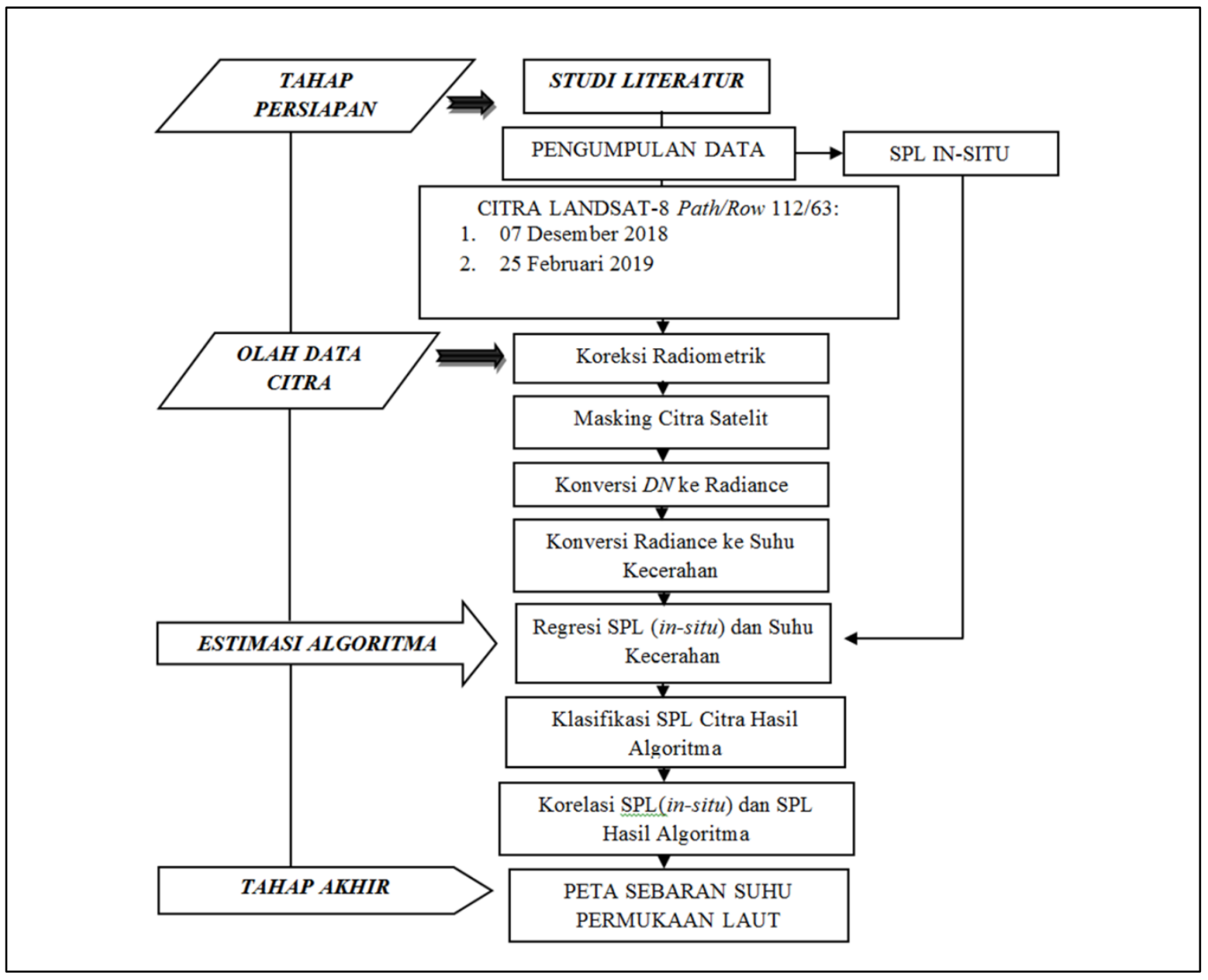

Gambar 2. Diagram Alir Penelitian

Adapun prosedur penelitian ini yaitu meliputi sumber data, survey pendahuluan, penentuan stasiun penelitian, pengambilan sampel suhu permukaan laut, pengolahan data dan analisis data. Diagram alir penelitian dapat dilihat pada Gambar 2.

a. Data Primer

- Data yang digunakan dalam penelitian ini yaitu data suhu permukaan laut yang diukur langsung dilapangan (in-situ) dengan menggunakan alat (thermometer Water Quality Meter). Pengukuran tersebut dilakukan di 20 titik stasiun penelitian. Pengambilan data lapangan (in-situ) dilakukan pada Tanggal 08 Desember 2018, Jam 15:30 - 17:34 WITA di Perairan Teluk Kendari.

- Data citra satelit Landsat-8 TIRS Daerah Perairan Teluk Kendari yang di download dari USGS (https://earthexplorer.usgs.gov). Waktu perekaman citra satelit 10:00 - 10:15 pagi Tanggal 07 Desember 2018. Berikut data citra satelit Landsat-8 yang digunakan dalam penelitian ini.

- Tahap survey pendahuluan dilaksanakan guna untuk mengetahui kondisi lokasi penelitian, penentuan titik koordinat menggunakan GPS, serta persiapan peralatan penunjang lainnya yang akan digunakan di lapangan (in-situ) dan memastikan ketersediaan data citra satelit Landsat-8 TIRS yang dibutuhkan ketika menganalisis sebaran suhu permukaan laut.

- Berdasarkan survey pendahuluan yang telah dilakukan, lokasi stasiun penelitian dan penentuan titik koordinat yaitu di Perairan Teluk Kendari dengan 20 titik stasiun penelitian. Penentuan titik tersebut telah mewakili sebagian dari sebaran suhu permukaan laut di Perairan Teluk Kendari, Sulawesi Tenggara. 
Tabel 1. Data Citra Satelit Landsat-8 TIRS

\begin{tabular}{cccccc}
\hline No & Tahun & Tanggal & Path/Row & Area & Nama file \\
\hline 1 & 2018 & 07 & $112 / 63$ & Perairan Kota & LC08_L1TP_112063_20181 \\
& & Desember & & Kendari & 207_20181211_01_T1.tar \\
\hline 2 & 2019 & 25 & $112 / 63$ & Perairan Kota & LC08_L1TP_112063_20190 \\
& & Februari & & Kendari & 225_20190309_01_T1.tar \\
\hline
\end{tabular}

Pengukuran suhu permukaan laut dilakukan dengan menggunakan thermometer Water Quality Meter dengan cara memasukan alat tersebut kedalam perairan dengan perkedalaman pengambilan $\mathrm{SPL} \pm 20-30 \mathrm{~cm}$, selama \pm 1 menit kemudian melihat angka yang tertera pada alat tersebut. Pengukuran suhu dilakukan pada setiap titik stasiun penelitian. Pengolahan citra satelit dilakukan dengan beberapa tahap, yaitu:

Koreksi Radiometrik

Koreksi radiometrik digunakan untuk mengkonversi nilai digital number (DN) menjadi nilai radian kemudian dikonversi kembali menjadi nilai reflektansi yang dianggap mewakili nilai sebenarnya dari kemampuan suatu obyek dilapangan dalam memantulkan gelombang elektromagnetik (Fadhliannor, 2015).

Meminimalisir kesalahan radiometrik akibat aspek eksternal berupa gangguan atmosfer pada saat proses perekaman. Biasanya gangguan atmosfer ini dapat berupa serapan, hamburan, dan pantulan yang menyebabkan nilai piksel pada citra hasil perekaman tidak sesuai dengan nilai piksel obyek sebenarnya di lapangan. Persamaan yang digunakan untuk koreksi radiometrik citra satelit landsat-8 yaitu sebagai berikut.

$\mathrm{NP}^{\prime}=\mathrm{NP}^{-\mathrm{NP}_{\min }}$

Keterangan:

NP' = Nilai piksel hasil koreksi

$\mathrm{NP} \quad=$ Nilai piksel citra

$\mathrm{NP}_{\min }=$ Nilai piksel minimum

Koreksi radiometrik dilakukan dengan menggabungkan band/kanal pada citra landsat8 yaitu band $11(10.50-12.51(\mu \mathrm{m}))$, band 10 $(10.60-11.19(\mu \mathrm{m}))$, band $5(0.85-0.88(\mu \mathrm{m}))$ dan band $2(0.45-0.51(\mu \mathrm{m}))$.

Masking Citra Satelit

Pemisahan daratan dan lautan merupakan sebuah upaya yang dilakukan untuk membatasi sebuah area yang akan dianalisis. Baik berupa analisis terhadap lingkungan atau ekosistem wilayah daratan dan analisis lingkungan atau ekosistem terhadap wilayah lautan. Adapun persamaan yang digunakan yaitu sebagai berikut.

IF(I1-I2)<0 THEN I3 ELSE NULL Cropping Citra Satelit Landsat-8 TIRS

Membuat gambar subset, atau "memotong," bertujuan untuk membatasi bidang minat, memperkuat fenomena geospasial, dan fokus pada area belajar. Selain itu, gambar subset menghasilkan benda-benda yang lebih besar dalam ukuran, memungkinkan ada informasi seperti warna agar terlihat lebih jelas.

Konversi Nilai DN (Digital Number) Ke Radiance

Radiasi adalah sumber energi yang merupakan hal utama dalam penginderaan jauh sebagai penyedia energi yang dipancarkan. Menghitung nilai radians citra menggunakan formula dari USGS yaitu, $\mathrm{L} \lambda=\mathrm{ML} \times$ Digital Number +AL, dimana: ML adalah radiance multiplier atau band-specific multiplicative rescaling faktor yang besarnya adalah 3,3420x10-4 dan AL adalah band specific radiance additive rescaling faktor band diperoleh dari metadatanya yang besarnya 0.1 . Adapun persamaan yang digunakan yaitu sebagai berikut.

$\mathrm{L} \lambda=\mathrm{ML} \times D N+\mathrm{AL}$

Konversi Nilai Radiance Ke Suhu Kecerahan (Brigthness Temperatur)

Suhu kecerahan adalah perhitungan dari intensitas radiasi termal yang diemisikan oleh obyek. Satuan yang digunakan adalah satuan suhu, sebab terdapat korelasi antara intensitas radiasi yang diemisikan dan suhu fisik dari badan radiasi, dimana diasumsikan bahwa emisi radiasi pada permukaan obyek berwarna hitam adalah 1,0 (Shofiyanti, 2007). Adapun persamaan yang digunakan yaitu sebagai berikut.

$$
B T=\frac{\mathrm{K}^{2}}{\operatorname{Ln}\left(\frac{\mathrm{K} 1}{\mathrm{~L} \lambda}\right)+1}-273
$$

Dimana $\mathrm{L} \lambda$ adalah nilai radiansi citra. $\mathrm{K}$ adalah konstanta, yang mana untuk 07 Desember 2015, nilai K1 dan K2 berturut turut untuk band 10 adalah 774.89 dan 1321.08 
sedangkan untuk band 11 adalah 480.89 dan 1201.14.

Klasifikasi Citra Satelit Landsat-8 TIRS

Klasifikasi citra satelit adalah suatu proses untuk mendapatkan citra yang telah dikelompokkan dalam beberapa kelas yang mewakili objek suatu perairan. Metode yang digunakan dalam klasifikasi citra satelit landsat-8 adalah klasifikasi draw raster grouping values into classes. Adapun citra yang diklasifikasi adalah citra satelit landsat- 8 Tahun 2014, 2018 dan 2019 pada aplikasi perangkat lunak ArcGis 10.3.

\section{Layout Citra Satelit Landsat-8 TIRS}

Layout peta SPL hasil klasifikasi citra satelit landsat-8 bertujuan untuk memberikan sebuah gambaran atau peta hasil sebaran suhu permukaan laut di Perairan Teluk Kendari, Sulawesi Tenggara. Menggunakan aplikasi perangkat lunak ArcGIS 10.3.

\section{Analisis Data}

(Pajrin, 2018) Analisis regresi bertujuan untuk mengetahui pengaruh satu atau lebih variabel independent/bebas $(\mathrm{x})$ terhadap satu variabel dependent/terikat (y) sehingga harus ditemukan terlebih dahulu mana variabel bebas dan variabel terikat. Analisis ini dilakukan untuk pendugaan variabel y dengan menggunakan variabel $\mathrm{x}$. adapun rumusnya yaitu sebagai berikut:

$\mathrm{y}=\mathrm{a}+\mathrm{bx}$

$\mathrm{a}=\frac{\left(\sum \mathrm{Yi}\right)\left(\sum \mathrm{X} i^{2}\right)-\left(\sum \mathrm{Xi}\right)\left(\sum \mathrm{XiYi}\right)}{n \sum \mathrm{X} i^{2}-\left(\sum \mathrm{X} i\right)^{2}}$

$\mathrm{b}=\frac{n \sum \mathrm{XiYi}-\left(\sum \mathrm{Xi}\right)\left(\sum \mathrm{Yi}\right)}{n \sum \mathrm{Xi}^{2}-\left(\sum \mathrm{Xi}\right)^{2}}$

Keterangan :

$\mathrm{y}=$ Data Suhu (in-situ) (variabel terikat)

$\mathrm{x}=$ Data Citra/DN (digital number) (variabel bebas)

$\mathrm{a}=$ Harga $\mathrm{y}$ bila $\mathrm{x}=0$ (harga konstan)

$\mathrm{b}=$ Koefisien Regresi yang menyatakan perubahan rata-rata variabel y untuk setiap perubahan variabel $\mathrm{x}$ sebesar satu unit.

Kemudian dilanjutkan dengan analisis korelasi, untuk menentukan hubungan antara kedalaman yang diperoleh lewat pemeruman dengan nilai spektral hasil transformasi dari formula Jupp, analisis korelasi yang digunakan adalah:

$\mathrm{r}=\frac{n\left(\sum \mathrm{XiYi}\right)-\left(\sum \mathrm{Xi}\right)\left(\sum \mathrm{Xi}\right)}{\sqrt{\left(n \sum \mathrm{X} i^{2}-\left(\sum \mathrm{X} i\right)^{2}\right)\left(n \sum \mathrm{Y} i^{2}-\left(\sum \mathrm{Y} i\right)^{2}\right)}}$

Keterangan:

$\mathrm{r}=$ Koefisien Korelasi $\mathrm{r}=-1$; menyatakan adanya hubungan linier sempurna tak langsung antar variabel (korelasi negatif). $r=+1$; menyatakan adanya hubungan linear sempurna langsung antar (korelasi positif). $\mathrm{r}=0$; menyatakan tidak terdapat hubungan linear antar variable. $\mathrm{n}=$ Jumlah data.

Analisis statistik diperlukan untuk menentukan tingkat keakurasian hasil estimasi SPL dari pengolahan dibeberapa citra satelit landsat-8 terhadap data lapangan (insitu). Terdapat 2 parameter yang digunakan untuk menentukan tingkat keakurasian, yaitu nilai koefisien determinasi $\left(\mathrm{R}^{2}\right)$ dan nilai $\mathrm{RE}$ (Relative Error).

$\begin{aligned} R^{2}= & \left(\frac{n\left(\sum \mathrm{y}\right)-\left(\sum \mathrm{x}\right)\left(\sum \mathrm{y}\right)}{\sqrt{\mathrm{n}\left(\sum x^{2}\right)-\left(\sum \mathrm{x}\right)^{2}} \sqrt{n\left(\sum y^{2}\right)-\left(\sum \mathrm{y}\right)^{2}}}\right)^{2} \\ R E= & \frac{1}{N} \sum_{i=1}^{N}\left|\frac{x_{\text {est } i, i}-x_{\text {meas }, i}}{x_{\text {meas }}}\right| x 100 \% \\ & \text { Syarat minimum terhadap nilai RE }\end{aligned}$ (Relative Error) agar bisa digunakan untuk mengekstrak sebuah data kualitas air dari data penginderaan jauh adalah $\leq 30 \%$ (Jaelani et al., 2015).

Analisis Spasial

Analisis spasial suhu permukaan laut yaitu dengan membandingkan sebaran suhu permukaan laut pada lokasi pengamatan (insitu) dengan data citra satelit. Selanjutnya klasifikasi nilai citra dilakukan bertujuan untuk mengelompokkan data suhu berdasarkan kelas dan warna tertentu, sehingga dapat diketahui sebaran spasial suhu permukaan laut di wilayah pengamatan/perairan (Zulfikar et al., 2016).

\section{Hasil dan Pembahasan}

Berdasarkan hasil penelitian yang telah dilakukan dilapangan (in-situ) pada Tanggal 08 Desember 2018, pukul 15:30 - 17:34 WITA, ditemukan bahwa sebaran suhu permukaan laut di 20 titik stasiun penelitian (Gambar 4), ratarata berkisar $30,6^{\circ} \mathrm{C}-33,1^{\circ} \mathrm{C}$ (Tabel 5). Menurut pernyataan dari Najib dan Astuti (2014) bahwa, pada bulan Desember, umumnya perairan di wilayah Indonesia mengalami tren peningkatan SPL dengan probabilitas $\geq 95 \%$. Menurut Gordon (2005) bahwa, tingginya nilai suhu permukaan laut di Perairan Indonesia disebabkan oleh posisi geografi Indonesia yang terletak diwilayah ekuator yang merupakan daerah penerima panas matahari terbanyak. Wilayah ekuator memiliki massa air permukaan hangat yang disebabkan oleh adanya pemanasan yang terjadi secara terus-menerus sepanjang tahun. 
Tabel 2. Hasil Regresi SPL (In-Situ) dan SPL Citra Satelit Landsat-8 TIRS Band 10.

\begin{tabular}{cccccccc}
\hline Band & $\begin{array}{c}\text { Nama } \\
\text { Fungsi }\end{array}$ & $\begin{array}{c}\text { Persamaan } \\
\text { Fungsi }\end{array}$ & $\begin{array}{c}\text { Koef. } \\
\text { Regresi } \\
\left(\mathrm{R}^{2}\right)\end{array}$ & Band & $\begin{array}{c}\text { Nama } \\
\text { Fungsi }\end{array}$ & Persamaan Fungsi & $\begin{array}{c}\text { Koef. } \\
\text { Regresi } \\
\left(\mathrm{R}^{2}\right)\end{array}$ \\
\hline 10 & Linear & $\mathrm{y}=1.5772 \mathrm{x}-$ & 0.7295 & 11 & Linear & $\mathrm{y}=0.6873 \mathrm{x}+$ & 0.5809 \\
& & 17.545 & & & & 8.8775 & \\
10 & Exponensial & $\mathrm{y}=7.062 \mathrm{e}^{0.0481 \mathrm{x}}$ & 0.7268 & 11 & Exponensial & $\mathrm{y}=15.173 \mathrm{3}^{0.0222 \mathrm{x}}$ & 0.5814 \\
10 & Logarithmic & $\mathrm{y}=50.171 \ln (\mathrm{x})$ & 0.7275 & 11 & Logarithmic & $\begin{array}{l}\mathrm{y}=21.818 \ln (\mathrm{x})- \\
44.739\end{array}$ & 0.5768 \\
& & -140.95 & & & & & \\
\hline
\end{tabular}

Pemanasan tersebut mengakibatkan terbentuknya stratifikasi didalam kolom perairan yang disebabkan oleh adanya gradien suhu. Hal ini menunjukkan bahwa, daerah ekuator merupakan daerah yang penting dalam mengendalikan cuaca dan iklim didaerah lain. Menurut Najib dan Astuti (2014) bahwa, perubahan ini mungkin sebagai bagian dari variasi natural, ataupun merupakan manifestasi lokal akibat pemanasan global yang disebabkan oleh gas rumah kaca dan aerosol akibat aktivitas manusia.

Kisaran suhu permukaan laut yang ditemukan di Perairan Teluk Kendari (insitu) tersebut dipengaruhi oleh beberapa faktor diantaranya adalah pendangkalan di Perairan Teluk Kendari. Pendangkalan disebabkan oleh proses sedimentasi yang tinggi sehingga radiasi sinar matahari lebih mudah menembus perairan dangkal. Hal ini sesuai pendapat dari (Arief et al., 2015) penelitian yang telah dilakukan di Perairan Teluk Betung bahwa, temperatur tertinggi berada di sepanjang garis pantai Teluk Betung dibandingkan dengan area pertengahan Teluk Betung. Hal ini disebabkan, sepanjang garis pantai tersebut terdapat banyak sampah yang diakibatkan oleh aktifitas masyarakat disekitarnya, dimana airnya kotor (berwarna kehitamhitaman). Sehingga membantu lebih cepat proses sedimentasi yang menyebabkan pendangkalan disuatu perairan.

Berdasarkan hasil penelitian, SPL (insitu) dan olahan suhu kecerahan (brigthness temperature) pada citra satelit Landsat- 8 TIRS band 10 diregresikan untuk mendapatkan algoritma estimasi, sebagai pendugaan suhu permukaan laut sebelum, (07 Desember 2018) dan sesudahnya (25 Februari 2019) (persamaan 5). Hasil regresi tersebut menunjukkan bahwa, SPL (in-situ) dan suhu kecerahan (brigthness temperature) citra satelit Landsat-8 TIRS band 10 memiliki nilai yang kuat dan mendekati nilai 1 (Tabel 2).

Algoritma estimasi yang digunakan yaitu, hasil analisis regresi linear band 10 yang dimana nilai regresi linear band 10 lebih kuat jika dibandingkan dengan hasil regresi exponensial dan logarithmic band 10 maupun hasil regresi linear, exponensial dan logarithmic band 11 (Tabel 3). Sehingga hasil analisis regresi tersebut menunjukkan bahwa, algoritma estimasi dapat digunakan untuk menganalisis SPL dan menyusun pola SPL (sea surface temperature) diperairan Teluk Kendari, Sulawesi Tenggara. Menurut Sugiyono (2007) bahwa, pedoman untuk memberikan interpretasi koefisien korelasi adalah sebagai berikut: $0,00-0,199=$ sangat rendah; $0,20-0,399=$ rendah; $0,40-0,599=$ sedang; $0,60-0,799=$ kuat; $0,80-1,000=$ sangat kuat.

Klasifikasi citra satelit LDCM-8 TIRS band 10 yang telah di analisis regresi antara SPL (in-situ) 08 Desember 2018 dan suhu kecerahan 07 Desember 2018 untuk menguji algoritma estimasi, ditemukan bahwa sebaran suhu permukaan laut di Perairan Teluk Kendari, Sulawesi Tenggara, berkisar antara $28,5^{\circ} \mathrm{C}-31,8^{\circ} \mathrm{C}$. Suhu tertinggi diwakili warna merah dengan nilai suhu sebesar $30,3^{\circ} \mathrm{C}-31,8^{\circ} \mathrm{C}$, untuk warna jingga mewakili nilai suhu perairan sebesar $29,5^{\circ} \mathrm{C}$ - $30,3^{\circ} \mathrm{C}$, warna kuning sendiri mewakili nilai suhu perairan sebesar $29,1^{\circ} \mathrm{C}-29,5^{\circ} \mathrm{C}$, sedangkan yang terakhir sekaligus suhu terendah berdasarkan hasil pengolahan data Citra Satelit Landsat- 8 untuk besar nilai suhu perairan $28,5^{\circ} \mathrm{C}-28,8^{\circ} \mathrm{C}$ diwakili dengan warna hijau tua . Najib dan Astuti (2014) menyatakan bahwa, umumnya pada musim Desember, Januari dan Februari (DJF), sebagian besar wilayah laut Indonesia mengalami tren peningkatan SPL. Tren peningkatan tertinggi berada di perairan sekitar Laut Sulawesi, Halmahera dan Laut Pasifik bagian barat. Luasan wilayah yang 
memiliki tren peningkatan SPL paling luas terjadi saat bulan Desember, kemudian semakin menyempit pada bulan Januari dan Februari. Menurut Hutabarat dan Evans (1984) bahwa, suhu permukaan laut rata-rata di Perairan Indonesia berkisar antara $28^{\circ} \mathrm{C}$ $31^{\circ} \mathrm{C}$ dan akan mengalami penurunan satu hingga dua derajat setiap kedalaman 80 meter. Kasus tertentu seperti upwelling, nilai suhu permukaan laut dapat turun menjadi $25^{\circ} \mathrm{C}$. Hal ini disebabkan karena air yang dingin dari lapisan bawah terangkat kepermukaan laut.

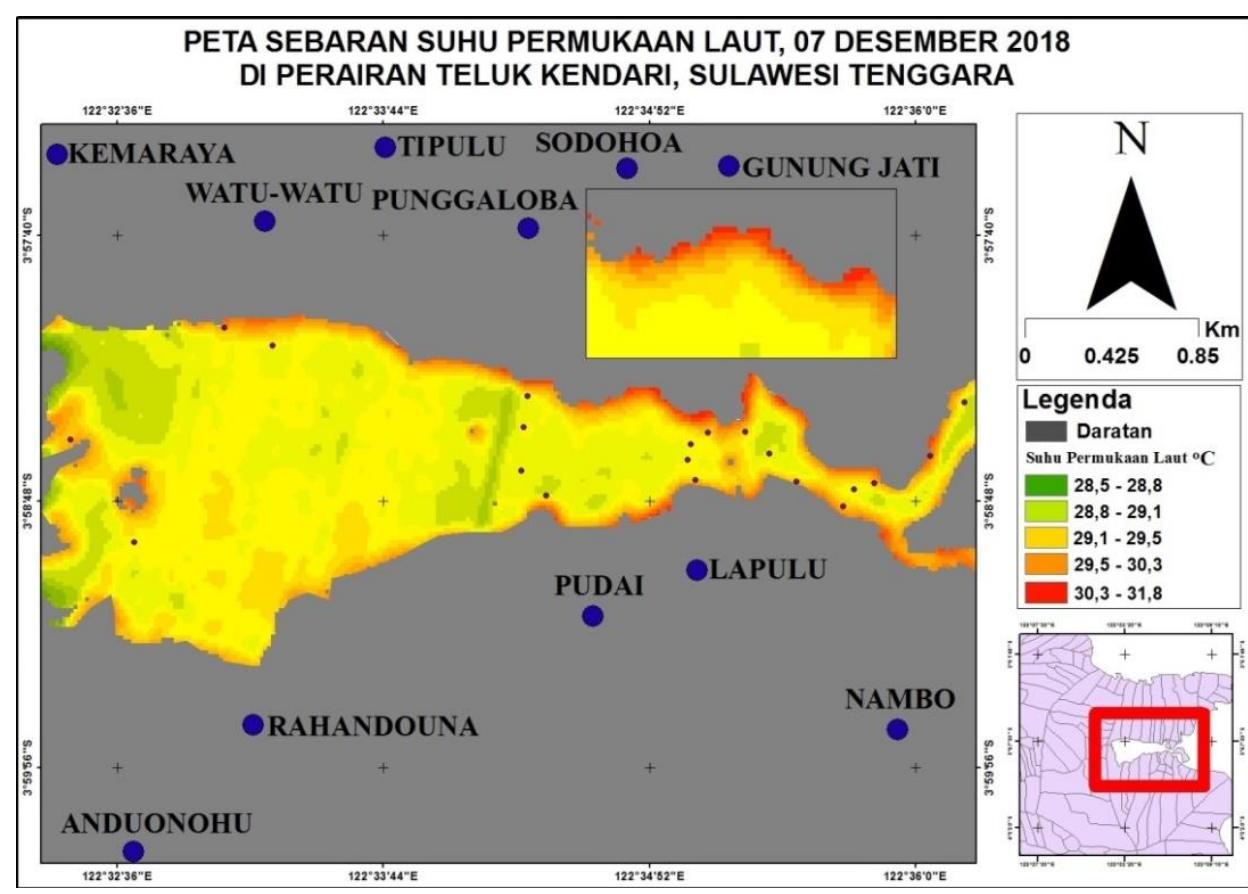

Gambar 3. Sebaran Suhu Permukaan Laut Hasil Analisa Citra Landsat-8 TIRS Menggunakan ER- MAPPER 7.0 (07 Desember 2018); Algoritma Estimasi

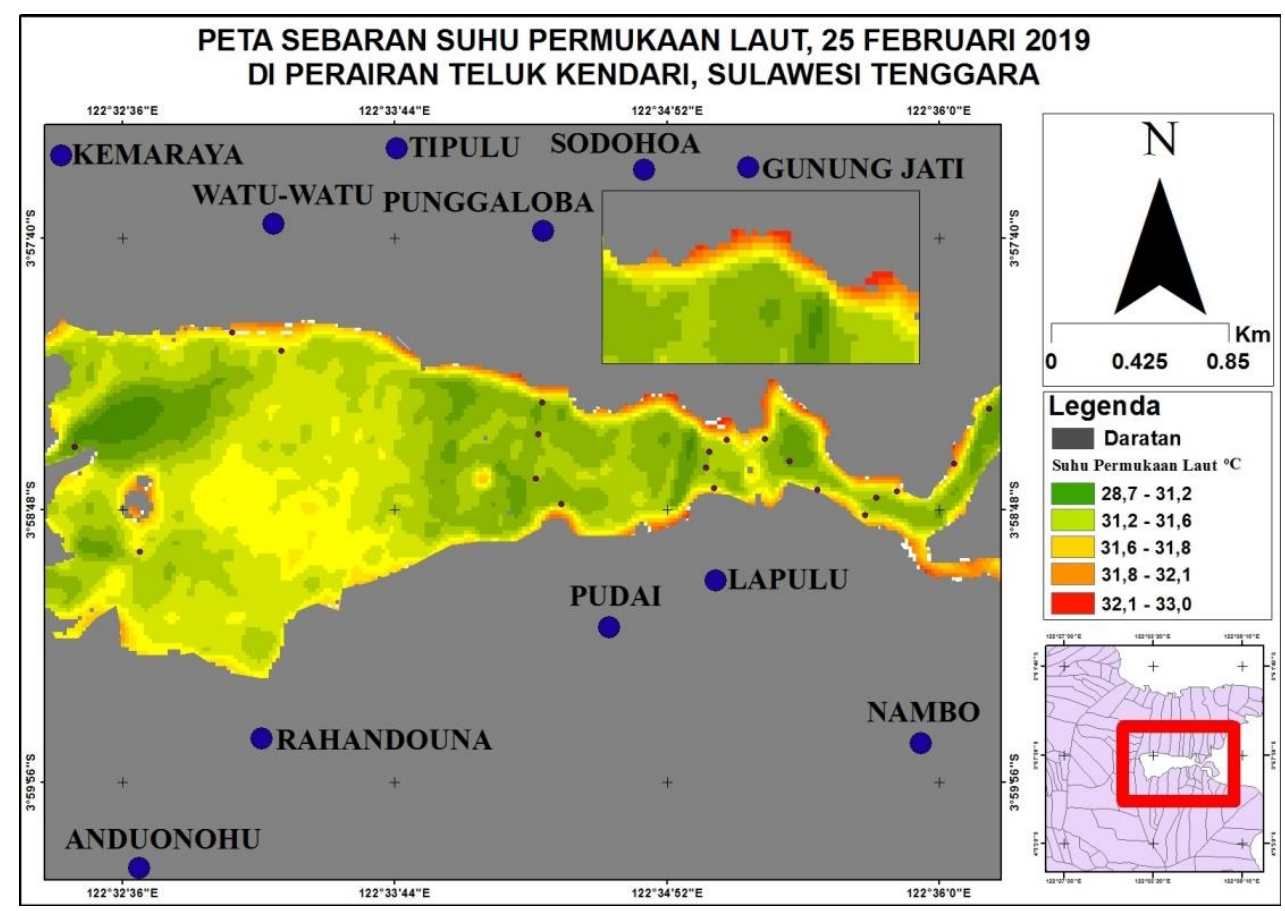

Gambar 4. Sebaran Suhu Permukaan Hasil Analisa Citra Landsat-8 TIRS Menggunakan 
ER-MAPPER 7.0 (25 Februari 2019); Algoritma Estimasi

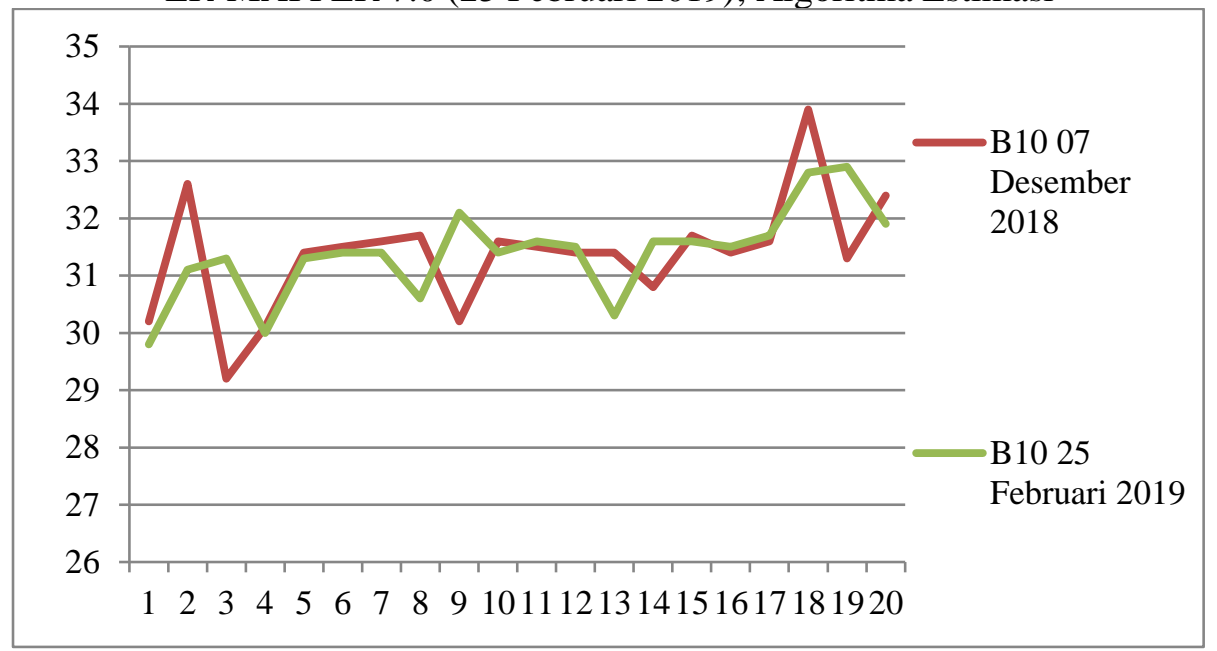

Gambar 5. Perbandingan SPL Citra Satelit Landsat-8 TIRS Band 10

Hasil akhir selanjutnya menjelaskan klasifikasi citra satelit LDCM-8 TIRS band 10 sebaran SPL di Perairan Teluk Kendari, Sulawesi Tenggara, 25 Februari 2019 berkisar $32,1^{\circ} \mathrm{C}-33,0^{\circ} \mathrm{C}$. Suhu tertinggi diwakili warna merah dengan nilai suhu sebesar $32,1^{\circ} \mathrm{C}$ $-33,0^{\circ} \mathrm{C}$, untuk warna jingga mewakili nilai suhu perairan sebesar $31,8^{\circ} \mathrm{C}-32,1^{\circ} \mathrm{C}$, warna kuning sendiri mewakili nilai suhu perairan sebesar $31,6^{\circ} \mathrm{C}-31,8^{\circ} \mathrm{C}$, sedangkan yang terakhir sekaligus suhu terendah berdasarkan hasil pengolahan data Citra Satelit Landsat-8 untuk besar nilai suhu perairan $28,7^{\circ} \mathrm{C}-$ $31,2^{\circ} \mathrm{C}$ diwakili dengan warna hijau tua. Menurut Dahuri (2004) bahwa, suhu permukaan laut (SPL) Indonesia secara umum berkisar antara $26-29^{\circ} \mathrm{C}$. Perairan Indonesia di pengaruhi oleh angin musim, maka sebaran suhu permukaan laut (SPL) mengikuti perubahan musim. Musim barat (Desember, Januari dan Februari) suhu permukaan laut di kawasan barat Indonesia pada umumnya lebih rendah dari pada musim timur (Juni, Juli dan Agustus). Menurut Nontji (1987) bahwa, suhu permukaan laut di perairan Indonesia berkisar antara $28^{\circ} \mathrm{C}-31^{\circ} \mathrm{C}$, namun pada beberapa wilayah di sekitar pembuangan limbah industri maupun pembangkit listrik suhu permukaan laut dapat mencapai $37^{\circ} \mathrm{C}$.

Garis plotting pada Gambar 5 diatas menunjukkan bahwa nilai SPL citra satelit LDCM-8 TIRS (Akuisisi, 07 Desember 2014) lebih tinggi jika dibandingkan dengan nilai SPL citra satelit LDCM-8 TIRS (Akuisisi, 25 Februari 2019). Disebabkan karena pada bulan Desember terjadi sebuah musim kemarau yang tinggi. Sedangkan pada bulan Februari merupakan bulan peralihan musim kemarau, menuju musim penghujan pada bulan Maret Agustus.

Tabel 3. Hubungan SPL (In-Situ) dan SPL Citra Landsat-8 TIRS band 10

\begin{tabular}{ccc}
\hline \multirow{3}{*}{ Korelasi (r) } & $\begin{array}{c}07 \\
\text { Desember } \\
2018\end{array}$ & $\begin{array}{c}25 \text { Februari } \\
2019\end{array}$ \\
\cline { 2 - 3 } & 0,76 & 0,65 \\
\hline
\end{tabular}

Hasil hubungan (korelasi) 07 Desember 2018 sebesar 0,76 dimana, korelasi (r) tersebut memiliki hubungan yang kuat, jika dibandingkan dengan korelasi (r) pada Tahun sesudahnya (25 Februari 2019). Hasil koefisien korelasi (r) 25 Februari 2019 sebesar 0,65 dimana, korelasi (r) tersebut juga memiliki hubungan yang kuat. Namun, korelasi (r) yang dihasilkan tidak > dari $70 \%$.

Gambar 6 menunjukkan bahwa, koefisien determinasi $\left(\mathrm{R}^{2}\right)$ SPL (in-situ) 08 Desember 2018 dan SPL citra satelit LDCM-8 TIRS band 10 (07 Desember 2018) mempunyai nilai koefisien determinasi $\left(\mathrm{R}^{2}\right)=$ 0.5881. koefisien determinasi $\left(\mathrm{R}^{2}\right)$ yang dihasilkan memiliki keterkaitan yang sedang. Namun, koefisien determinasi $\left(\mathrm{R}^{2}\right)$ tersebut tidak > dari $70 \%$. Faktor yang menjadi penyebab $\left(\mathrm{R}^{2}\right)$ SPL (in-situ) dan SPL citra LDCM-8 TIRS band 10 tidak > dari 70\% yaitu, terjadinya perubahan lingkungan seperti radiasi matahari, kelembapan udara, curah hujan, arus laut, kecepatan angin serta aktivitas-aktivitas masyarakat di Perairan Teluk Kendari yang selalu berubah-ubah tiap waktunya. 


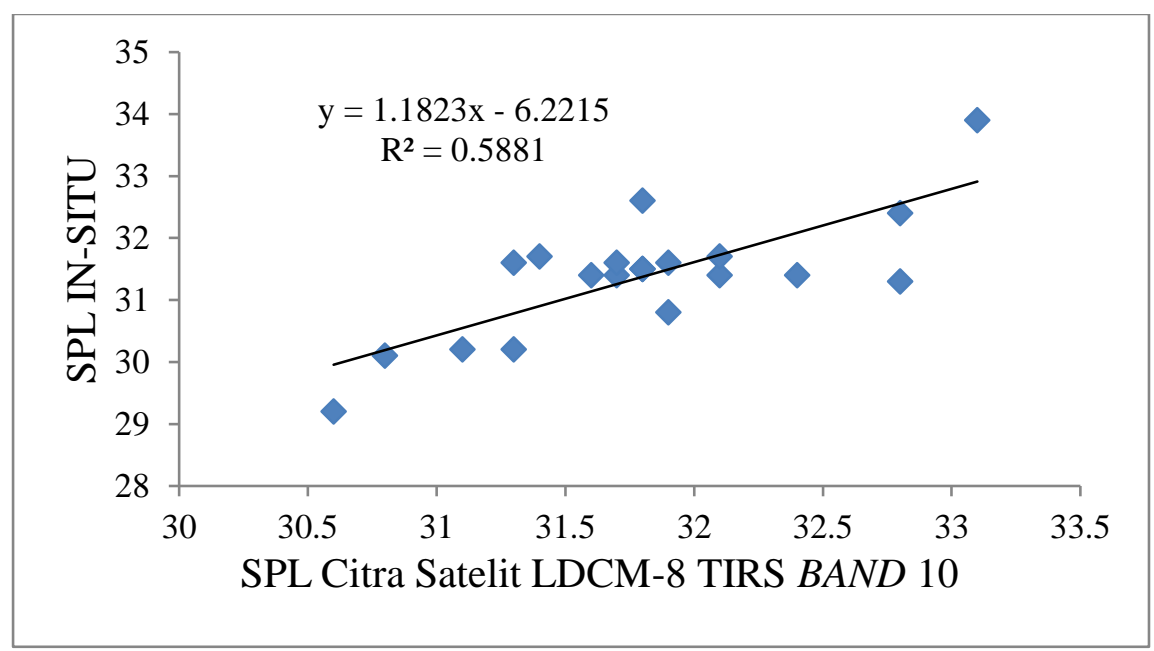

Gambar 6. Hubungan SPL (In-Situ) dan SPL citra LDCM-8 TIRS 07 Desember 2018

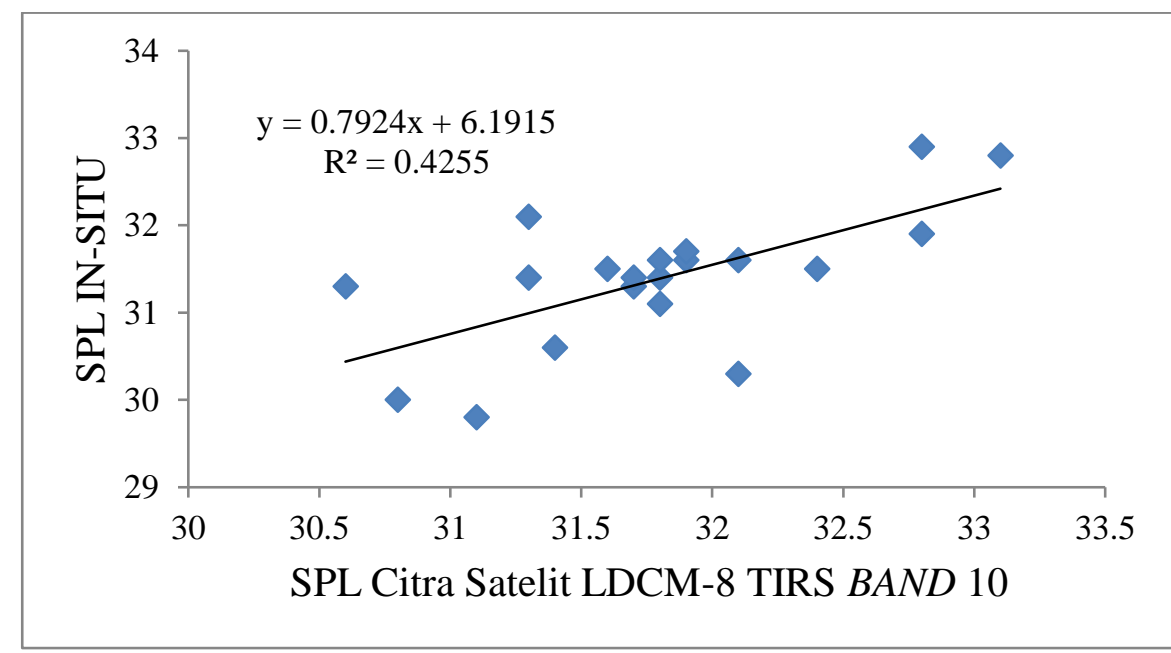

Gambar 7. Hubungan SPL (In-Situ) dan SPL citra LDCM-8 TIRS 25 Februari 2019

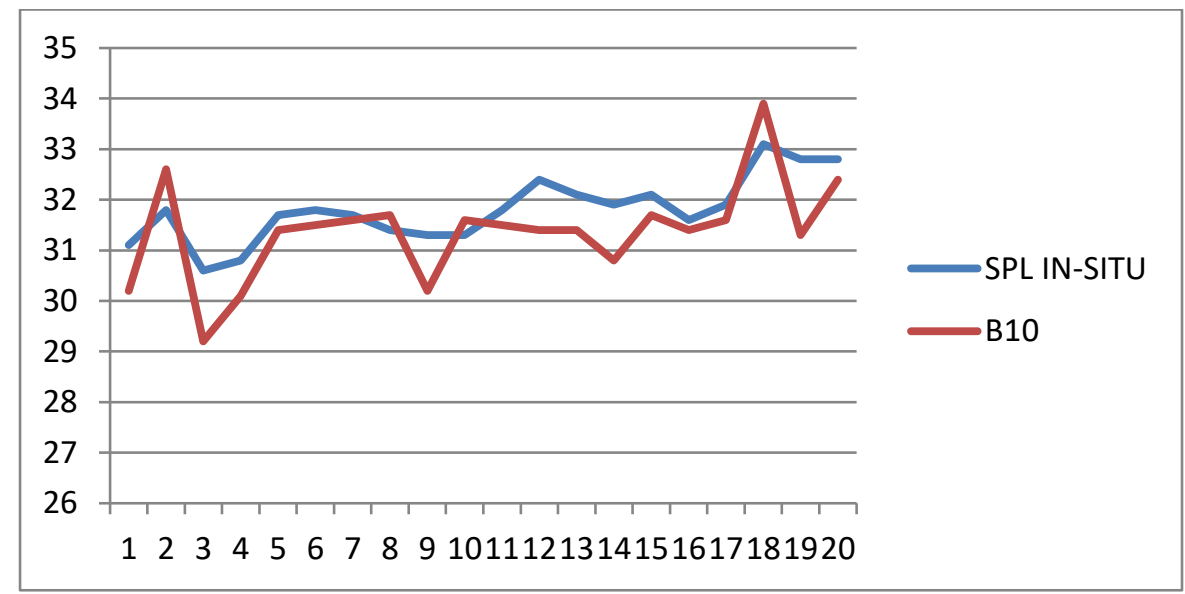

Gambar 8. Perbandingan SPL (In-Situ) dan Hasil Estimasi SPL Citra Band 1007 Desember 2018 


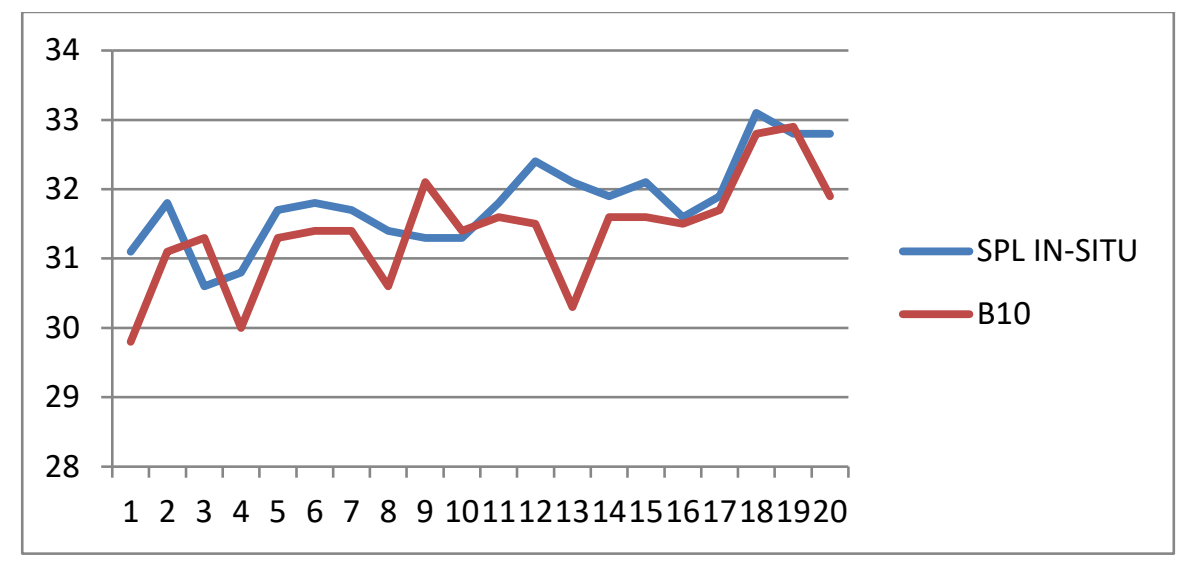

Gambar 9. Perbandingan SPL (In-Situ) dan Hasil Estimasi SPL Citra Band 1025 Februari 2019

Tabel 4. Nilai Kesalahan Relatif \{Relative Error (RE) \} Suhu Permukaan Laut

\begin{tabular}{|c|c|c|c|c|c|}
\hline \multirow{3}{*}{ ST } & \multirow{3}{*}{ SPL INSITU } & \multicolumn{4}{|c|}{ Tanggal Perekaman Citra Satelit Landsat-8 TIRS } \\
\hline & & \multicolumn{2}{|c|}{$7 / 12 / 2018$} & \multicolumn{2}{|c|}{ 25/02/2019 } \\
\hline & & (B10) & $\mathbf{R E}$ & (B10) & $\mathbf{R E}$ \\
\hline 1 & 31,1 & 30,2 & 0.029801 & 29,8 & 0.043624 \\
\hline 2 & 31,8 & 32,6 & -0.02454 & 31,1 & 0.022508 \\
\hline 3 & 30,6 & 29,2 & 0.047945 & 31,3 & -0.02236 \\
\hline 4 & 30,8 & 30,1 & 0.023256 & 30,0 & 0.026667 \\
\hline 5 & 31,7 & 31,4 & 0.009554 & 31,3 & 0.01278 \\
\hline 6 & 31,8 & 31,5 & 0.009524 & 31,4 & 0.012739 \\
\hline 7 & 31,7 & 31,6 & 0.003165 & 31,4 & 0.009554 \\
\hline 8 & 31,4 & 31,7 & -0.00946 & 30,6 & 0.026144 \\
\hline 9 & 31,3 & 30,2 & 0.036424 & 32,1 & -0.02492 \\
\hline 10 & 31,3 & 31,6 & -0.00949 & 31,4 & -0.00318 \\
\hline 11 & 31,8 & 31,5 & 0.009524 & 31,6 & 0.006329 \\
\hline 12 & 32,4 & 31,4 & 0.031847 & 31,5 & 0.028571 \\
\hline 13 & 32,1 & 31,4 & 0.022293 & 30,3 & 0.059406 \\
\hline 14 & 31,9 & 30,8 & 0.035714 & 31,6 & 0.009494 \\
\hline 15 & 32,1 & 31,7 & 0.012618 & 31,6 & 0.015823 \\
\hline 16 & 31,6 & 31,4 & 0.006369 & 31,5 & 0.003175 \\
\hline 17 & 31,9 & 31,6 & 0.009494 & 31,7 & 0.006309 \\
\hline 18 & 33,1 & 33,9 & -0.0236 & 32,8 & 0.009146 \\
\hline 19 & 32,8 & 31,3 & 0.047923 & 32,9 & -0.00304 \\
\hline 20 & 32,8 & 32,4 & 0.012346 & 31,9 & 0.028213 \\
\hline
\end{tabular}

Gambar 7 menunjukkan bahwa, koefisien determinasi $\left(\mathrm{R}^{2}\right)$ SPL (in-situ) dan SPL citra satelit LDCM-8 TIRS band 10 (25 Februari 2019) mempunyai nilai koefisien determinasi $\left(\mathrm{R}^{2}\right)=0,4255$. koefisien determinasi $\left(\mathrm{R}^{2}\right)$ yang dihasilkan memiliki keterkaitan yang sedang. Seperti pada tahun sebelumnya, hubungan SPL (in-situ) dan SPL citra Landsat-8 TIRS band 10 tidak melebihi dari $70 \%$ sebab efek global warming (pemanasan global) yang dapat mencairkan es di daerah kutub sehingga menyebabkan perubahan musim dan iklim yang terjadi tiap tahunnya serta menyebabkan arus, gelombang, gerakan konveksi, upwelling, divergensi selalu berubah-ubah tiap tahunnya. 
Gambar 8 dan 9 menunjukkan bahwa, garis plotting 07 Desember 2018 nilai SPL band 10 lebih tinggi jika dibandingkan dengan SPL (in-situ). 25 Februari 2019 menunjukkan bahwa, garis plotting pada tahun tersebut nilai SPL (in-situ) lebih tinggi jika dibandingkan dengan nilai SPL citra satelit LDCM-8 TIRS band 10. Sebaran SPL (in-situ) dan SPL citra satelit LDCM-8 TIRS band 10 masing-masing garis plotting suhu yang dihasilkan tidak sama.

Berdasarkan hasil uji akurasi antara suhu permukaan laut (in-situ) dengan hasil estimasi citra satelit Landsat-8 TIRS band 10 di Perairan Teluk Kendari didapatkan jumlah nilai $\sum \mathrm{RE}$ (Relative Error) 07 Desember 2018 sebesar 28,0\% dan $\sum$ RE 25 Februari 2019 sebesar 26,6\% (Tabel 5). Hal tersebut menunjukkan bahwa, algoritma estimasi dapat diterapkan di Perairan Teluk Kendari karena besar kesalahan hasil pengolahan citra satelit adalah $<30 \%$ dimana menurut Purwadhi (2001) bahwa, syarat minimum NMAE (Normalized Mean Absolute Error) kesalahan relatif rata-rata kurang dari $30 \%$ pada pengolahan data citra sehingga dapat digunakan untuk analisa lebih lanjut.

\section{Simpulan}

Adapun simpulan dalam penelitian ini yaitu, suhu permukaan laut di Perairan Teluk Kendari, Sulawesi Tenggara pada Tanggal 08 Desember 2018, berkisar $30,6^{\circ} \mathrm{C}-33,1^{\circ} \mathrm{C}$. Sedangkan SPL citra satelit Landsat-8 TIRS band 10 berdasarkan algoritma estimasi 07 Desember 2018 dan 25 Februari 2019, berkisar $28,5^{\circ} \mathrm{C}-33,0^{\circ} \mathrm{C}$.

\section{Daftar Pustaka}

Arief, M. Adawiah, S, W. Parwaty, E. Hamzah, R. Prayogo, R. 2015. Pengembangan Model Ekstraksi Suhu Permukaan LautMenggunakan Data Satelit Landsat 8, Studi Kasus: Teluk Lampung. Jurnal Penginderaan Jauh. Vol 12: (2). 107-122 Hal.

Fachruddin, A, S. 2010. Penginderaan Jauh dan Aplikasinya di Wilayah Pesisir dan Lautan. Jurnal Kelautan. Vol. 3: (1). 18 - $28 \mathrm{Hal}$.

Gordon, A.L. 2005. Oceanography of the Indonesian Seas dan Their Throughflow. Jurnar Oceanography. Vol 18: (4). 27 Pages.
Najib, M. H dan Astuti, T. N. 2014. Karakteristik dan Tren Perubahan Suhu Permukaan Laut di Indonesia Periode 1982-2009. Vol 15: (1). 37-49 Hal.

Nontji, A. 1987. Laut Nusantara. Djambatan, Jakarta.

Purwadhi, F. 2001. Interpretasi Citra Digital. Grasindo, Jakarta. 